\title{
Water Intake and Digestive Metabolism of Broilers Fed All-Vegetable Diets Containing Acidulated Soybean Soapstock ${ }^{1}$
}

\section{author(s) \\ Vieira SL \\ Viola ES \\ Berres J \\ Coneglian JLB \\ Freitas DM \\ Bortolini TCK}

Departamento de Zootecnia

Universidade Federal do Rio Grande do Sul

\section{Mail Address}

\section{SL Vieira}

Departamento de Zootecnia

Universidade Federal do Rio Grande do Sul

Av. Bento Gonçalves, 7712

91.540-000. Porto Alegre, RS, Brasil

Telefone/Fax: 555133166048

E-mail slvieira@ufrgs.br

Keywords

Acidulated soybean soapstock, all vegetable diets, broiler, metabolizability, water intake.

'Suporte da Fapergs

\section{ABSTRACT}

A study was conducted to compare live performance and digestive metabolism of broiler chickens fed all-vegetable diets (All-Veg) compared to a regular diet including animal by-products. Three feeds were formulated and provided to broilers according to the feeding program: pre-starter from 1 to 10 days, starter from 11 to 21 days, and grower from 21 to 35 days. All feeds had corn and soybean meal as major ingredients; however, two of them were all-vegetable diets having either Degummed Soybean Oil (DSO) or Acidulated Soybean Soapstock (ASS) as fat sources. The third diet included poultry by-product and poultry fat. A total number of 360 day-old broiler chicks were allocated to $1 \mathrm{~m}^{2}$ battery cages, 10 chicks in each, and 12 replicates per treatment. Live performance was similar between groups of birds receiving the different diets with the exception of weight gain, which was increased for birds fed the All-Veg diet with ASS. Birds fed All-Veg diets had increased water intake and produced more excreta with a concurrent reduced feed metabolizability at both ages, regardless of fat source. Metabolizable Energy was not different for the three diets.

\section{INTRODUCTION}

The European Community banned the inclusion of animal by-products in feeds for animals raised for human consumption, including poultry, as part of the strategy to control the spread the "Mad Cow Disease" (Bovine Spongiform Encephalopathy-BSE) (CEC, 2000). This decision was later also adopted by other countries, such as Saudi Arabia.

Feeding chickens exclusively with plant-based ingredients is a practice which contrasts with their natural habits, because these animals evolved in habitats with a great variety of available foods, such as fruits, worms, insects, and all sorts of seeds (Fumihito et al., 1994). In practical terms, the formulation of broiler feeds exclusively with vegetal ingredients requires a greater inclusion of soybean meal. In comparison with feeds including animal by-products, all vegetable corn-soybean meal feeds (All-Veg) have 25\% higher potassium content (NRC, 1994; Rostagno et al., 2000), which was shown that increases water intake of broilers in 20\% (Vieira et al., 2003).

Soybean meal carbohydrate fraction has high percentages of cellulose, pectin, hemicelluloses, and oligosaccharides, which have reduced energy availability for poultry as compared to swine (Potter \& Potchanakorn, 1985; NRC, 1994; NRC, 1998). Pectin and hemicelluloses may potentially produce alterations in the gastrointestinal environment and in excreta viscosity (Langhout \& Schutte, 1996). High excreta viscosity and an increased number of anaerobes were found in broilers fed diets with $4.5 \%$ of pectin (Wagner \& Thomas, 1978), which was also related to nutrient utilization and acceleration of feed passage 


\section{Vieira SL, Viola ES, Berres J, Coneglian JLB, Freitas DM, Bortolini TCK}

Water Intake and Digestive Metabolism of Broilers Fed All-Vegetable Diets Containing Acidulated Soybean Soapstock through the intestinal tract (Coen et al., 1997; Shah et al., 1982). Soybean predominant oligosaccharides, stachyose and raphynose, are highly fermentable, increasing the feed passage and therefore reducing digestibility (Coon et al., 1990; Leske et al., 1991; Leske et al., 1993; Leske \& Coon, 1999; Saini, 1989; Steggerda, 1968).

Acidulated soybean soapstocks (ASS) are produced through the acid treatment of the residue remaining after neutralization of vegetal fat used for human consumption. Several types of vegetal fats, consisting of mixtures or of single source, have been used in broiler feeds. Acidulated soybean soapstock may have up to $70 \%$ free fatty acids (Lipstein \& Bornstein, 1968). Emulsification deficiencies due to smaller amounts of monoglycerides in ASS limit energy utilization from ASS by broilers as compared to DSO (Bornstein \& Lipstein, 1963; Sklan, 1979).

Acidulated soapstocks are low cost fats. However, they still have limited use due to misinformation related to origin and to available energy. Vieira et al. (2002) and Machado et al. (2003) demonstrated that the ASS can be included in broiler diets in up to $8 \%$ without negatives effects on live performance. Machado et al. (2003) determined ME values for DSO and ASS in broilers with one and five weeks of age, and found values of 8,351 and 7,701 kcal ME/kg for the first week, and 9,314 and 8,559 kcal ME/kg for the fifth week, respectively. Similar values were found by Freitas et al. (2005).

This study aimed at comparing the impact of the utilization of broiler feeds formulated with animal byproducts with those formulated exclusively with plantbased ingredients. Investigation was performed on growth performance, and efficiency of feed utilization of birds with two different ages, simulating the present requirements of the internal market versus that of Europe and Saudi Arabia.

\section{MATERIAL AND METHODS}

A total number of 308 Ross $X$ Ross male day-old broiler chicks were obtained from a commercial hatchery. They were housed in $401.0-\mathrm{m}^{2}$ steel battery cages placed in a temperature-controlled room regulated to maintain bird comfort until $35 \mathrm{~d}$ of age. Birds had ad libitum access to feeds in a program including pre-starter ( 0 to $10 \mathrm{~d}$ ), starter (11 to $21 \mathrm{~d}$ ) and grower (21 to $35 \mathrm{~d}$ ) diets. Corn-soybean meal feeds were divided in three experimental dietary treatment groups with twelve replicates each. These diets were fed to six chicks per battery cage as follows: diet formulated exclusively with plant and plant-derived ingredients supplemented either with DSO (Veg-DSO) or ASS (Veg-ASS), or diet formulated with variable inclusions of poultry by-product supplemented with poultry fat (Animal). Diets in all feeding programs were formulated to have similar energy and nutrients (Tables 1, 2 and 3). Before preparing the experimental feeds, each ingredient was analyzed for crude protein, $\mathrm{Ca}$ and $P$, which values were used in feed formulation. Other nutrients and energy were based on data from Rostagno et al. (2000), except for DSO and ASS ME values, which were previously determined by Machado et al. (2003) as 8,351 and 7,701 kcal ME/kg for the first week (used to formulate pre-starter diets); and 9,314 and 8,559 kcal $\mathrm{ME} / \mathrm{kg}$ for the fifth week of age (used to formulate starter and grower diets). Feeds were all in the mash form.

\begin{tabular}{|c|c|c|c|}
\hline \multicolumn{4}{|c|}{$\begin{array}{l}\text { Table } 1 \text { - Composition of broiler diets formulated exclusively } \\
\text { with plant ingredients or having animal by-products from } 1 \\
\text { to } 10 \text { days of age. }\end{array}$} \\
\hline Ingredient, $\%$ & $\begin{array}{l}\text { Acidulated } \\
\text { Soybean } \\
\text { Soapstock } \\
\text { Veg-ASS }\end{array}$ & $\begin{array}{l}\text { Degummed } \\
\text { Soybean Oil } \\
\text { Veg-DSO }\end{array}$ & $\begin{array}{l}\text { Animal By } \\
\text {-Products } \\
\text { Animal }\end{array}$ \\
\hline Corn & 46.99 & 48.31 & 63.27 \\
\hline Soybean meal & 42.38 & 41.96 & 19.54 \\
\hline Dicalcium phosphate & 1.72 & 1.71 & 0.32 \\
\hline Limestone & 1.20 & 1.19 & 0.19 \\
\hline Salt & 0.56 & 0.56 & 0.41 \\
\hline DL-Methionine & 0.30 & 0.30 & 0.27 \\
\hline L-Lysine $\mathrm{HCl}$ & 0.05 & 0.06 & 0.18 \\
\hline L-Threonine & - & - & 0.02 \\
\hline Choline chloride & 0.11 & 0.11 & 0.04 \\
\hline Vitamin mineral premix ${ }^{1}$ & 0.45 & 0.45 & 0.45 \\
\hline $\begin{array}{l}\text { Acidulated soybean } \\
\text { soapstock }\end{array}$ & 6.24 & - & - \\
\hline Degummed soybean oil & - & 5.34 & - \\
\hline Poultry by-product & - & - & 15.33 \\
\hline $\begin{array}{l}\text { Total } \\
\text { Energy and Nutrients }\end{array}$ & 100 & 100 & 100 \\
\hline $\mathrm{ME}, \mathrm{kcal} / \mathrm{kg}$ & 3,000 & 3,000 & 3,000 \\
\hline Crude protein & 23.0 & 23.0 & 23.0 \\
\hline $\mathrm{Ca}$ & 1.0 & 1.0 & 1.0 \\
\hline Av.P. & 0.74 & 0.74 & 0.74 \\
\hline $\mathrm{Na}$ & 0.24 & 0.24 & 0.24 \\
\hline K & 0.95 & 0.94 & 0.64 \\
\hline $\mathrm{Cl}$ & 0.26 & 0.27 & 0.27 \\
\hline $\mathrm{Na}+\mathrm{K}+\mathrm{Cl}, \mathrm{mEq} / \mathrm{kg}$ & 273 & 271 & 193 \\
\hline Lysine & 1.30 & 1.30 & 1.30 \\
\hline Met + Cys & 0.96 & 0.96 & 0.96 \\
\hline Threonine & 0.87 & 0.87 & 0.87 \\
\hline Tryptophan & 0.28 & 0.28 & 0.28 \\
\hline Digestible lysine & 1.15 & 1.15 & 1.15 \\
\hline Digestible Met + Cys & 0.86 & 0.86 & 0.86 \\
\hline Digestible threonine & 0.72 & 0.72 & 0.72 \\
\hline Digestible tryptophan & 0.24 & 0.24 & 0.20 \\
\hline
\end{tabular}

2 - Supplemented per kg: Vit A 8,000 UI; Vit D3 2,000 Ul; Vit E 30 mg; Vit K3 20 mg; Vit B1 2.0 mg; Vit B2 6.0 mg; Vit B6 2.5 mg; Vit B12 $0.012 \mathrm{mg}$, Panthotenic Acid $15 \mathrm{mg}$; Niacin $35 \mathrm{mg}$; Folic Acid $1.0 \mathrm{mg}$; Biotin $0.08 \mathrm{mg}$; Iron $100 \mathrm{mg}$; Cupper $8 \mathrm{mg}$; lodine $0.5 \mathrm{mg}$; Manganese $80 \mathrm{mg}$, Selenum $0.5 \mathrm{mg}$; Zinc $70 \mathrm{mg} .2$ - As percentage or otherwise described. 


\section{Vieira SL, Viola ES, Berres J, Coneglian JLB, Freitas DM, Bortolini TCK}

\begin{tabular}{|c|c|c|c|}
\hline Ingredient, \% & $\begin{array}{c}\text { Acidulated } \\
\text { Soybean } \\
\text { Soapstock } \\
\text { Veg-ASS }\end{array}$ & $\begin{array}{c}\text { Degummed } \\
\text { Soybean Oil } \\
\text { Veg-DSO }\end{array}$ & $\begin{array}{l}\text { Animal By } \\
\text {-Products } \\
\text { Animal }\end{array}$ \\
\hline Corn & 49.85 & 53.31 & 67.34 \\
\hline Soybean meal & 38.33 & 36.23 & 14.02 \\
\hline Dicalcium phosphate & 1.75 & 1.75 & 0.26 \\
\hline Limestone & 1.19 & 1.17 & 0.12 \\
\hline Salt & 0.56 & 0.56 & 0.40 \\
\hline DL-Methionine & 0.31 & 0.33 & 0.28 \\
\hline L-Lysine $\mathrm{HCl}$ & 0.13 & 0.19 & 0.24 \\
\hline L-Threonine & 0.03 & 0.05 & 0.04 \\
\hline Choline chloride & 0.09 & 0.10 & 0.02 \\
\hline Vitamin Mineral Premix ${ }^{1}$ & 0.35 & 0.35 & 0.35 \\
\hline $\begin{array}{l}\text { Acidulated soybean } \\
\text { soapstock }\end{array}$ & 7.41 & - & the \\
\hline Degummed soybean oil & - & 5.96 & - \\
\hline Poultry by-product & - & - & 16.31 \\
\hline Poultry fat & - & - & 0.62 \\
\hline $\begin{array}{l}\text { Total } \\
\text { Energy and Nutrients }{ }^{2}\end{array}$ & 100 & 100 & 100 \\
\hline $\mathrm{ME}, \mathrm{kcal} / \mathrm{kg}$ & 3,100 & 3,100 & 3,100 \\
\hline Crude protein & 21.5 & 21.5 & 21.5 \\
\hline $\mathrm{Ca}$ & 1.0 & 1.0 & 1.0 \\
\hline Av. P. & 0.73 & 0.73 & 0.73 \\
\hline $\mathrm{Na}$ & 0.24 & 0.24 & 0.24 \\
\hline K & 0.88 & 0.88 & 0.56 \\
\hline $\mathrm{Cl}$ & 0.28 & 0.28 & 0.28 \\
\hline $\mathrm{Na}+\mathrm{K}+\mathrm{Cl}, \mathrm{mEq} / \mathrm{kg}$ & 251 & 249 & 168 \\
\hline Lysine & 1.26 & 1.26 & 1.26 \\
\hline Met + Cys & 0.94 & 0.94 & 0.94 \\
\hline Threonine & 0.83 & 0.83 & 0.83 \\
\hline Tryptophan & 0.26 & 0.26 & 0.26 \\
\hline Digestible lysine & 1.12 & 1.12 & 1.11 \\
\hline Digestible Met + Cys & 0.69 & 0.70 & 0.68 \\
\hline Digestible threonine & 0.22 & 0.21 & 0.20 \\
\hline Digestible tryptophan & 0.84 & 0.84 & 0.83 \\
\hline
\end{tabular}

1 - Supplemented per kg: Vit A 8,000 Ul; Vit D3 2,000 UI; Vit E $30 \mathrm{mg}$; Vit K3 $20 \mathrm{mg}$; Vit B1 $2.0 \mathrm{mg}$; Vit B2 $6.0 \mathrm{mg}$; Vit B6 $2.5 \mathrm{mg}$; Vit B12 $0.012 \mathrm{mg}$, Panthotenic Acid $15 \mathrm{mg}$; Niacin $35 \mathrm{mg}$; Folic Acid $1.0 \mathrm{mg}$; Biotin $0.08 \mathrm{mg}$; Iron $100 \mathrm{mg}$; Cupper $8 \mathrm{mg}$; lodine $0.5 \mathrm{mg}$; Manganese 80 mg, Selenum 0.5 mg; Zinc 70 mg. 2 - As percentage or otherwise described.

The supplemental fats used in this study were obtained from reliable suppliers, and had values of moisture + impurity + unsaponifiables lower than $1 \%$.

Birds in each replicate were weighed at placement, and at 7, 21, and 35 days of age, when feed intake and feed conversion ratio were also calculated. Water intake was daily recorded from 3 to $10 \mathrm{~d}$ of age, subtracting the volume remaining at the end of each 24-h period from the total allocated volume at the beginning. This procedure was carefully managed to avoid any water spillage. The amount of evaporated water was estimated with blank drinkers placed in cage batteries without birds. Estimated evaporated water was then added to the values of water remaining in drinkers at the end of each 24-h period.

\begin{tabular}{|c|c|c|c|}
\hline Ingredient, \% & $\begin{array}{c}\text { Acidulated } \\
\text { Soybean } \\
\text { Soapstock } \\
\text { Veg-ASS }\end{array}$ & $\begin{array}{l}\text { Degummed } \\
\text { Soybean Oil } \\
\text { Veg-DSO }\end{array}$ & $\begin{array}{c}\text { Animal By } \\
\text {-Products } \\
\text { Animal }\end{array}$ \\
\hline Corn & 57.51 & 588.1 & 64.29 \\
\hline Soybean meal & 32.26 & 318.6 & 22.32 \\
\hline Dicalcium phosphate & 1.53 & 15.3 & 0.92 \\
\hline Limestone & 1.26 & 12.5 & 0.82 \\
\hline Salt & 0.46 & 3.7 & 0.39 \\
\hline DL-Mehtionine & 0.32 & 3.2 & 0.31 \\
\hline L-Lysine & 0.20 & 2.1 & 0.25 \\
\hline L-Threonine & 0.05 & 0.05 & 0.05 \\
\hline Choline chloride & 0.08 & 0.08 & 0.05 \\
\hline Vitamin Mineral Premix & 0.34 & 0.34 & 0.34 \\
\hline Acidulated soybean soap & pstock6.00 & 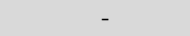 & - \\
\hline Degummed soybean oil & - & 5.18 & - \\
\hline Poultry by-product & - & - & 6.72 \\
\hline Poultry fat & - & - & 3.54 \\
\hline $\begin{array}{l}\text { Total } \\
\text { Energy and Nutrients }{ }^{2}\end{array}$ & 100 & 100 & 100 \\
\hline $\mathrm{ME}, \mathrm{kcal} / \mathrm{kg}$ & 3,180 & 3,180 & 3,180 \\
\hline Crude protein & 19.5 & 19.5 & 19.5 \\
\hline $\mathrm{Ca}$ & 1.0 & 1.0 & 1.0 \\
\hline Av.P. & 0.68 & 0.68 & 0.68 \\
\hline $\mathrm{Na}$ & 0.20 & 0.20 & 0.20 \\
\hline K & 0.79 & 0.78 & 0.66 \\
\hline $\mathrm{Cl}$ & 0.28 & 0.28 & 0.28 \\
\hline $\mathrm{Na}+\mathrm{K}+\mathrm{Cl}, \mathrm{mEq} / \mathrm{kg}$ & 210 & 208 & 176 \\
\hline Lysine & 1.17 & 1.17 & 1.17 \\
\hline Met + Cys & 0.90 & 0.90 & 0.90 \\
\hline Threonine & 0.77 & 0.77 & 0.77 \\
\hline Tryptophan & 0.23 & 0.23 & 0.23 \\
\hline Digestible lysine & 1.04 & 1.04 & 1.03 \\
\hline Digestible Met + Cis & 0.66 & 0.66 & 0.65 \\
\hline Digestible threonine & 0.19 & 0.19 & 0.18 \\
\hline Digestible tryptophan & 0.81 & 0.81 & 0.8 \\
\hline
\end{tabular}

1 - Supplemented per kg: Vit A 8,000 Ul; Vit D3 2,000 Ul; Vit E $30 \mathrm{mg}$; Vit K3 20 mg; Vit B1 2.0 mg; Vit B2 6.0 mg; Vit B6 2.5 mg; Vit B12 $0.012 \mathrm{mg}$, Panthotenic Acid $15 \mathrm{mg}$; Niacin $35 \mathrm{mg}$; Folic Acid $1.0 \mathrm{mg}$; Biotin $0.08 \mathrm{mg}$; Iron $100 \mathrm{mg}$; Cupper $8 \mathrm{mg}$; lodine $0.5 \mathrm{mg}$; Manganese $80 \mathrm{mg}$, Selenum $0.5 \mathrm{mg}$; Zinc $70 \mathrm{mg}$. 2 - As percentage or otherwise described.

Total excreta produced from 3 to 10 , and from 28 to 35 days, was collected from each battery cage three times a day (8:00 AM; 12-Noon, and 4:00 PM) following the procedures described by Gonzalez-Esquerra and Leeson (2000). Total excreta from each cage were homogenized after the last collection and weighed. A sample averaging 100 grams was taken from each pool, and oven-dried at $105{ }^{\circ} \mathrm{C}$ until weight loss was stabilized for dry matter calculation. Feed consumption was considered as the total amount fed within the period from 12 hours before the beginning to 12 hours before the end of excreta collection. Feed dry matter metabolizability was calculated for each period of collection by dividing the total feed retained (total consumption minus total excretion) by the total feed 


\section{Vieira SL, Viola ES, Berres J, Coneglian JLB, Freitas DM, Bortolini TCK}

consumption. Apparent Metabolizable Energy, corrected for retained nitrogen, was calculated after Gross Energy determination in a Parr Calorimeter as described by Muztar \& Slinger (1981).

Data were submitted to Analysis of Variance using SAS (2000). Tukey test was used to separate the means from the treatments, when significance was higher than $5 \%$.

\section{RESULTS AND DISCUSSION}

Body weight gain throughout the experiment showed an improvement for broilers fed the all vegetable diet supplemented with ASS as compared to the diet supplemented with DSO (Table 4). Differences were observed in the total gain from 1 to 35 days, and also during the periods of 1 to 7 and 7 to 21 days. However, body weight of birds fed Veg-ASS was not different of those fed the Animal diet. Similar responses were observed for feed conversion ratio. Feed intake and mortality did not differ between the three treatments (Tables 5 and 6).
Water intake and metabolism results from 3 to 10 days are presented in Tables 7 and 8, respectively. Both All-Veg diets had similar water intakes, which were higher than that observed for birds fed the Animal diet. Feed dry matter metabolizability was reduced with both All-Veg diets as compared to the Animal one, regardless of supplemental fat.

Birds fed the All-Veg diets produced excreta with higher moisture content as compared to those fed the Animal diet. There was no difference between the two fat sources for this response, or between treatments for the ME values determined with both ages. This is an indication that the ME values utilized for the ingredients in feed formulation were adequate for formulation of iso-energetic diets.

The domestic chicken has extensive ability to adapt to different habitats and feedstuffs. This has contributed for the success of the chicken meat industry around the world. However, production efficiency varies among geographic regions in the planet, depending on the availability of natural resources. Animal by-product inclusion in poultry feeds

\begin{tabular}{|c|c|c|c|c|c|c|}
\hline \multicolumn{7}{|c|}{ Days } \\
\hline & 1 & $1-7$ & $7-21$ & $1-21$ & $21-35$ & $1-35$ \\
\hline Treatment & 0.7569 & 0.0122 & 0.0730 & 0.0337 & 0.5780 & 0.0073 \\
\hline Animal & 47 & $118 a b$ & 674 & $791 \mathrm{ab}$ & 653 & $1444 a b$ \\
\hline Veg-ASS & 47 & $125 a$ & 708 & $834 a$ & 660 & $1494 a$ \\
\hline Veg-DSO & 47 & $110 \mathrm{~b}$ & 678 & $788 b$ & 637 & $1425 b$ \\
\hline Mean & 47 & 117 & 686 & 803 & 648 & 1452 \\
\hline$C V, \%$ & 1.71 & 10.27 & 5.73 & 6.63 & 8.01 & 3.44 \\
\hline
\end{tabular}

Means followed by the same letter are not different (Tukey, $p<0.05$ ).

Table 5 - Feed intake of broilers fed diets formulated with animal by-products or exclusively with plant based ingredients containing acidulated soybean soapstock, $g$

\begin{tabular}{|c|c|c|c|c|c|}
\hline \multicolumn{6}{|c|}{ Days } \\
\hline & $1-7$ & $7-21$ & $1-21$ & $21-35$ & $1-35$ \\
\hline Treatment & 0.2566 & 0.2101 & 0.1417 & 0.2150 & 0.0969 \\
\hline Animal & 131 & 898 & 1,145 & 1,215 & 2,225 \\
\hline Veg-ASS & 138 & 930 & 1,193 & 1,264 & 2,309 \\
\hline Veg-DSO & 131 & 901 & 1,142 & 1,268 & 2,248 \\
\hline Mean & 133 & 908 & 1.157 & 1.250 & 2.258 \\
\hline$C V, \%$ & 5.45 & 5.50 & 6.21 & 6.77 & 4.38 \\
\hline
\end{tabular}

Means followed by the same letter are not different (Tukey, $\mathrm{p}<0.05$ ).

Table 6 - Feed conversion of broilers fed diets formulated with animal by-products or exclusively with plant based ingredients containing acidulated soybean soapstock.

\begin{tabular}{lccccc} 
& \multicolumn{5}{c}{ Days } \\
\cline { 2 - 5 } & $\mathbf{1 - 7}$ & $\mathbf{7 - 2 1}$ & $\mathbf{1 - 2 1}$ & $\mathbf{2 1 - 3 5}$ & $\mathbf{1 - 3 5}$ \\
Treatment & 0.0257 & 0.6406 & 0.7857 & 0.0576 & 1659 \\
Animal & $1.114 \mathrm{ab}$ & 1.334 & 1.448 & $1.861 \mathrm{a}$ & 1.541 \\
Veg-ASS & $1.102 \mathrm{a}$ & 1.313 & 1.430 & $1.915 \mathrm{ab}$ & 1.545 \\
Veg-DSO & $1.188 \mathrm{~b}$ & 1.329 & 1.449 & $1.991 \mathrm{~b}$ & 1.578 \\
Mean & 1.135 & 1.325 & 1.442 & 1.922 & $\mathbf{6}$ \\
CV, \% & 6.68 & 3.52 & 4.47 & 3.64 \\
\hline
\end{tabular}

Means followed by the same letter are not different (Tukey, $p<0.05$ ). 


\section{Vieira SL, Viola ES, Berres J, Coneglian JLB, Freitas DM, Bortolini TCK}

\begin{tabular}{|c|c|c|c|c|c|}
\hline & $\begin{array}{l}\text { Water Intake } \\
\mathrm{mL} / \text { bird }\end{array}$ & $\begin{array}{c}\text { Dry Matter } \\
\text { Metabolizability, \% }\end{array}$ & $\begin{array}{l}\mathrm{ME}, \mathrm{kcal} / \mathrm{kg} \\
\text { Dry Matter }\end{array}$ & $\begin{array}{c}\text { Excreta Dry } \\
\text { Matter, g/bird }\end{array}$ & $\begin{array}{c}\text { Excreta } \\
\text { Moisture, \% }\end{array}$ \\
\hline Treatment & 0.0001 & 0.0001 & 0.1108 & 0.0003 & 0.0039 \\
\hline Animal & $331 b$ & $84.3 \mathrm{a}$ & 3,347 & $45 a$ & $67.2 \mathrm{a}$ \\
\hline Veg-ASS & $403 a$ & 79.8 b & 3,341 & $56 c$ & $68.4 \mathrm{ab}$ \\
\hline Veg-DSO & $386 a$ & $81.1 \mathrm{~b}$ & 3,391 & $49 \mathrm{~b}$ & $68.7 \mathrm{~b}$ \\
\hline Mean & 371 & 81.8 & 3,359 & 50.0 & 68.1 \\
\hline$C V, \%$ & 5.30 & 2.07 & 1.93 & 14.4 & 0.97 \\
\hline
\end{tabular}

Means followed by the same letter are not different (Tukey, $p<0.05$ ).

Table 8 - Metabolism responses of broilers fed diets formulated with animal by-products or exclusively with plant based ingredients containing acidulated soybean soapstock from 28 to 35 days of age.

\begin{tabular}{lcccc} 
& $\begin{array}{c}\text { Dry Matter } \\
\text { Metabolizability, \% }\end{array}$ & $\begin{array}{c}\text { ME, kcal/kg } \\
\text { Dry Matter }\end{array}$ & $\begin{array}{c}\text { Excreta Dry } \\
\text { Matter, g/bird }\end{array}$ & $\begin{array}{c}\text { Excreta } \\
\text { Moisture, \% }\end{array}$ \\
Treatment & 0.0001 & 0.1462 & 0.0001 & 0.0231 \\
Animal & $85.5 \mathrm{a}$ & 3,476 & $123 \mathrm{a}$ & $64.3 \mathrm{a}$ \\
Veg-ASS & $80.9 \mathrm{~b}$ & 3,440 & $160 \mathrm{~b}$ & $65.5 \mathrm{ab}$ \\
Veg-DSO & $81.5 \mathrm{~b}$ & 3,411 & $157 \mathrm{~b}$ & $65.8 \mathrm{~b}$ \\
Mean & 82.7 & 3,441 & 147 & 34.48 \\
CV, $\%$ & 2.63 & 2.33 & 13.9 & 4.83 \\
\hline
\end{tabular}

Means followed by the same letter are not different (Tukey, $p<0.05$ ).

has been a regular practice for a long time wherever chickens are grown. As these are cheap ingredients, they have been an important factor to maintain price competitiveness for poultry products, but they are also important to eliminate their disposal in the environment. The banning of animal by-products in diets for broilers destined to the European Community and Saudi Arabia led to an increased inclusion of vegetable protein sources. In practical terms, the option is usually to increase the usage of soybean products due to availability and cost.

Nutritionists and field technical personnel have been experiencing difficulties to maintain production efficiency since the requirement for the use of vegetarian feeds became a reality in Brazil. Problems are related to increased litter moisture, as well as higher frequency and intensity of feet dermatitis. Water intake obtained in this study from 3 to 10 days of age was higher in All-Veg diets. There is a well-known linear relationship between this electrolyte and water intake: birds have increase water intake in $3.29 \mathrm{ml}$ for each 1 mEq potassium in the feed (James \& Wheeler, 1949; Smith et al., 2000). In the present study, a water intake increase of $19 \%$ was observed in birds fed vegetable diets as compared to those fed the diet containing poultry by-product. A similar result was found with 5week-old birds (Vieira et al., 2003). Increased water intake is benefic during high temperatures. However, it increases litter moisture, which is highly correlated with feet dermatitis and poor environmental quality for broiler chickens (Martland, 1984; Martland, 1985).
The intestinal tract of the chicken is relatively short as compared with mammals. High passage rate, such as that of chickens, implies an efficient mechanism for digestion and absorption (Larbier \& Leclercq, 1992). Therefore, the chicken appears to be better adapted to the digestion of ingredients with higher digestibility. In general, animal by-products have high nutritional density and digestibility for birds.

Chickens, as opposed to ruminants and swine, do not have well-adapted structures for fermentative processes, which would allow fiber utilization. In adult birds, the caeca are the only structures with microorganisms and fatty acids (Annison et al., 1968; Johansson et al., 1948; McNab, 1973). However, no more than $25 \%$ of the total ingested feed enters the caeca (Son et al., 2002), which are located at the end of the digestive system, bearing, therefore, limitations in time and contact for efficient absorption of endproducts. Consequently, there is an obvious reduction in the potential for utilization of corn-soybean meal vegetarian feeds as compared to those including good quality animal by-products.

Soybean meal is an excellent source of protein and amino acids; however, it has very poor energy availability. Swine are able to retrieve 3,000 kcal ME/ $\mathrm{kg}$ from soybean meal, whereas this efficiency in poultry is 20\% lower (NRC, 1994; NRC, 1998). Differences between these species are, however, minimal for corn. Limitations in energy utilization reside on the non-protein fraction of soybean meal. Soybean carbohydrates consist of hemicelluloses, pectins, and 


\section{Vieira SL, Viola ES, Berres J, Coneglian JLB, Freitas DM, Bortolini TCK}

oligosaccharides (Eldridge et al., 1979). While the first and second are mostly present in the cell wall, demanding fermentation for the production of available energy, oligosaccharides lead to high production of hydrogen while inside the intestinal tract, which are useless for the bird (Cristofaro et al., 1974; Leske et al., 1991; Leske \& Coon, 1999). Therefore, the reduced metabolizability of diets formulated exclusively with plant ingredients find support in the existing differences in the carbohydrate fraction of soybean meal (Potter \& Potchanakorn, 1985). This factor, in addition of increased excreta moisture, is responsible for the higher amount of excreta produced with this type of feed.

Acidulated soapstocks are known to have lower available energy for poultry as compared to their original degummed oils (Sklan, 1979). Energy estimations for ASS are in average $9 \%$ lower than those for DSO. Therefore, losses in feed efficiency are observed when DSO are replaced by ASS is done on a weigh-by-weight basis (Bornstein \& Lipstein, 1963; Artman, 1964; Lipstein \& Bornstein, 1968). In this study, feed formulation utilized previously determined ME values for ASS and DSO (Machado et al., 2003), which led to similar responses in feed intake between Veg-ASS and VegDSO diets. Better weight gain and feed efficiency were observed in birds consuming diets supplemented with ASS as compared to those fed DSO. There were no differences in energy utilization between treatments at both ages. Therefore, there are other possibilities to explain this performance improvement. During the process of soybean oil refining, many important nutrients and other significant substances for animal health are frequently taken to the soapstock, which later will be used for ASS production. This is the case of Vitamin E, which is four times more concentrated in ASS than in DSO (340.3 mg alpha-tocopherol per $\mathrm{kg}$ ) (USDA, 2004). Lecithin, which is very rich in choline, but also isoflavones, is also present in high concentrations in ASS as compared to DSO (Rostagno et al., 2000; Yang et al., 2001).

\section{CONCLUSIONS}

Including poultry by-product in a corn-soybean meal diet leads to a reduction in water intake and excreta moisture as compared to a corn-soybean meal vegetarian diet, whereas feed dry matter metabolizability is increased.

Acidulated Soybean Soapstock supplementation of corn-soybean meal diets vegetarian diets allows similar
Water Intake and Digestive Metabolism of Broilers Fed All-Vegetable Diets Containing Acidulated Soybean Soapstock

live performance as compared to feeds containing poultry by-products.

\section{REFERENCES}

Annison EF, Hill KJ, Kenworth R. Volatile fatty acids in the digestive tract of the fowl. British journal of nutrition 1968; 22:207-216.

Artman NR. Interactions of fats and fatty acids as energy sources for the chick. Poultry science 1964; 43:994-1004.

Bornstein S, Lipstein B. Some unusual waste vegetable oil as fat supplements in practical broiler rations. World's Poultry Science Journal 1963; 19:172-184.

CEC. Council regulation 2000/766 concerning certain protection measures with regard to transmissible spongiform encephalopathies and the feeding of animal protein. Official Journal of European Communities 2000; 43(L306):32-33.

Coen HMS, Martin AV, Verstegen WA, Beynen ACB. Dietary carboxymethylcellulose with high instead of low viscosity reduces macronutrient digestion in broiler chickens. Journal of Nutrition 1997; 127:483-487.

Coon CN, Leske KL, Akavanichan O, Cheng TK. Effect of oligosaccharides-free soybean meal on true metabolizable energy and fiber digestion in adult roosters. Poultry Science 1990; 69: 787-793.

Cristofaro E, Mottu F, Wurhrmann JJ. Involvement of the raffinose family of oligosaccharides in flatulence. In: Sepple HL, Mcnutt KW, editors. Sugars in nutrition. New York: Academic Press; 1974. p.313363.

Eldridge AC, Black LT, Wolf WJ. Carbohydrate composition of soybean flours, protein concentrates, and isolates. Journal of Agriculture and Food Chemistry 1979; 27:799-802.

Freitas ER, Sakomura NK, Neme R, Santos AL. Valor enegético do óleo ácido de soja para aves. Pesquisa Agropecuária Brasileira 2005; 40:241-246

Fumihito A, Miyake T, Sumi S, Takada M, Ohno S, Kondo N. One subspecies of the red jungle fowl (Gallus gallus gallus) suffices as the matriarch ancestor of all domestic breeds. Proceedings of the National Academy of Sciences 1994; 91:1205-1209.

Gonzales-Esquerra R, Leeson S. Studies on the metabolizable energy content $f$ ground full-fat flaxseed fed in mash, pellet and crumbled diets assayed with birds of different ages. Poultry Science 2000; 1603-1607.

James EC, Wheeler RS. Relation of dietary protein content to water intake, water elimination and amount of cloacal excreta produced by growing chickens. Poultry Science 1949; 28:465-467.

Johansson KR, Sarles WB, Shapiro SK. The intestinal microflora of hens as influenced by various carbohydrates in a biotin deficient ration. Journal of Bacteriology 1948; 619-634. 


\section{Vieira SL, Viola ES, Berres J, Coneglian JLB, Freitas DM, Bortolini TCK}

Langhout DJ, Schutte JB. Nutritional implications of pectins in chicks in relation to esterification and origin of pectins. Poultry Science 1996; 75:1236-1242.

Langhout DJ, Schutte JB, De Jong J, Sloetjes $H$, Verstegen MWA, Tamminga $S$. Effect of viscosity on digestion of nutrients in conventional and germ-free chicks. British Journal of Nutrition 2000; 83:533-540.

Larbier M, Leclercq B. Nutrition and feeding of poultry. Nottingham: Nottigham University Press, Sutton Bonington Campus; 1994. 305 p.

Leske $\mathrm{KL}$, Coon $\mathrm{CN}$. Hydrogen gas production of broiler chicks in response to soybean meal and alpha-galactoside free, ethanolextracted soybean meal. Poultry Science 1999; 78:1313-1316.

Leske KL, Jevne CJ, Coon CN. Effect of oligosaccharides additions on nitrogen corrected true metabolizable energy of soy concentrate. Poultry Science 1993; 72:664-668.

Leske KL, Akavanichan O, Cheng TK, Coon CN. Effect of ethanol extract on nitrogen-corrected true metabolizable energy for soybean meal with broilers and roosters. Poultry Science 1991; 70:892895.

Lipstein B, Bornstein S. Lack of interference between dietary acidulated soybean soapstock and calcium in chicks and laying hens. Poultry Science 1968; 47:1905-1911.

Machado LP, Vieira SL, Quadros VR. Source level and age differences in fat utilization by broilers. Poultry Science 2003; 82:39.

Martland MF. Wet litter as a cause of plantar pododermatites leading to foot ulceration and lameness in fattening turkeys. Avian Pathology 1984; 13:241-252.

Martland MF. Ulcerative dermatitis in broiler chickens. The effects of wet litter. Avian Pathology 1985; 14:353-364.

McNab JM. The avian caeca: a review. World's Poultry Science Journal 1973; 29:251-263.

Muztar AJ, Slinger SJ. An evaluation of the nitrogen correction in the true metabolizable energy assay. Poultry Science 1981; 60:835839.

National Research Council. Nutrient requirements of poultry. $9^{\text {th }}$ ed. Washington: National Academy Press; 1994. 155 p.

National Research Council. Nutrient requirements of swine. $10^{\text {th }}$ ed. Washington: National Academy Press; 1998. 189 p.

Potter LM, Potchanakorn M. Digestibility of the carbohydrate fraction of soybean meal by poultry. Proceedings of the $3^{\text {rd }}$ world soybean conference. Boulder: Westview Press; 1985. p.218-224.

Rostagno HS, Albino LFT, Donzele IJL, Gomes PC, Ferreira AS, Oliveira RF, Lopes DC. Tabelas brasileiras para aves e suínos: composição de alimentos e exigências nutricionais. Viçosa: UFV; 2000
SAS Institute. Sas user's guide: statistics. Version 8 edition. Cary: SAS Institute; 2000.

Shah N, Atallah MT, Mahoney RR, Pelleti PL. Effect of dietary fiber components on fecal nitrogen excretion and protein utilization in growing rats. Journal of Nutrition 1982; 112:658-666.

Sklan D. Digestion and absorption of lipids in chicks fed triglycerides or free fatty acids: synthesis of monoglycerides in the intestine. Poultry Science 1979; 58:885-889.

Smith A, Rose SP, Wells RG, Pirgozliev V. Effect of excess dietary sodium, potassium, calcium and phosphorus on excreta moisture of laying hens. British Poultry Science 2000; 41:598-607.

Son JH, Ragland D, Adeola O. Quantification of digesta flow into de caeca. British Poultry Science 2002; 43:322-324.

Steggerda FR. Gastrointestinal gas following food consumption. Annals of the New York Academy of Sciences 1968; 150:57-66.

USDA 2004. WWW.ARS.USDA.GOV (falta dados: Autor. Título. data acesso)

Vieira SL, Ribeiro AML, Kessler AM, Fernandes LM, Ebert AR, Eichner G. Utilização da energia de dietas para frangos de corte formuladas com óleo ácido de soja. Brazilian Journal of Poultry Science 2002; 4 suppl 4:127-131.

Vieira SL, Lima IL, Borges CAQ, Fernandes LM, Quadros VR. Broiler utilization of vegetarian diets. Poultry Science 2003; 82:38.

Wagner DD, Thomas OP. Influence of diets containing rye or pectin on the intestinal flora of chicks. Poultry Science 1978; 57:971-975.

Yang CS, Landau JM, Huang MT, Newmark HL. Inhibition of carcinogenesis by dietary polyphenolic compounds. Annual Review of Nutrition 2001: 21:381-406. 